\title{
Female Foeticide and Gender Inequality in India: Issue of Attention
}

\author{
Pollypriya Buragohain
}

\begin{abstract}
In spite of a high rate of growth and ample government initiatives to maintain equality in case of gender, the gap between genders still exist in India. In India, based on their sex, gender variation is usually prescribed as the injustice or discrimination against women. Gender inequality limits women's participation in various fields and it also hampers the life of the future generation also. Women are confronted with many hurdles in everywhere. Female foeticide is one of the worst types of discrimination against females where a female is refused her most essential and fundamental right, i.e. the right to live life. In India, female foeticide means outside of valid law, the abortion of a female foetus. In India, the recurrence of female foeticide is expanding day by day. In present day, it seems that the sex determination test leading to the practice of female foeticide overlooked and uncomplicated than before. Since ancient days, killing of female foetus is an extraordinary feature under the rule of patriarchy in Indian society. According to census report, the child sex ratio has decreased from 945 girls (0-6 years) per 1000 boys (0-6 years) in 1991 it is 927 girls per 1000 boys in 2001 to 919 girls per 1000 boys in 2011. The picture of female foeticide in North-East India is quite good as compared to the other states of India. As per the census 2011, Arunachal Pradesh has the highest child ratio among the Indian states i.e. 972 while Haryana has the lowest child sex ratio i.e. 834 per thousand males. According to decennial Indian census, the sex ratio in the 0 to 6 age group in India has risen from 102.4 males per 100 females in 1961, to 104.2 in 1980 , to 107.5 in 2001 , to 108.9 in 2011. On this background, here, an attempt has been made to examine the issue of female foeticide as an indicator of gender inequality in India. This paper is mostly descriptive in nature entirely based on secondary data.
\end{abstract}

Key Words: Gender inequality, Female foeticide, Child sex ratio, India.

\section{INTRODUCTION}

In simple words, Female foeticide means the abortion of a female foetus outside of legal prescribed methods. i.e. it may be defined as the destruction of a female foetus at any stage of pregnancy period after determining the sex of the foetus. Through induced abortion killing of female foetus is also known as female foeticide. In India, the recurrence of female foeticide is expanding day by day. As per data, the natural sex ratio is estimated to between 103 and 107 where any number which is stand above it is counted as female foeticide. Because of affordable upgraded ultrasound technology in India, the phenomenon of female foeticide was almost started in the early 1990s. This type of technology came to India during 1979 but its spread was slow and later it became expand during 2000s.

Revised Manuscript Received on April 22, 2019.

* Correspondence Author

Pollypriya Buragohain*, Research Scholar, Department of Economics, Dibrugarh University, Assam E mail id: pollypriyaburagohain@gmail.com

(C) The Authors. Published by Blue Eyes Intelligence Engineering and Sciences Publication (BEIESP). This is an open access article under the CC BY-NC-ND license (http://creativecommons.org/licenses/by-nc-nd/4.0/)
In India, more than 10 million fetuses (female) have been terminated due to the reason of being girl. As son is preferred as family asset and daughter is a liability; people considered that male babies are superior because they provide labour and also lead the family ancestry in future.

In spite of a high growth rate and ample government measures to maintain gender equality, the gap between genders still exist in India. In India, based on their sex, gender variation is usually prescribed as the injustice or discrimination against women. Gender inequality limits women's participation in various fields and it also hampers the life of the future generation also. Female foeticide is one of the worst forms of discrimination against females where a female is refused her most essential and fundamental right, i.e. "the right to life".

\section{SIGNIFICANCE OF THE STUDY}

Gender disparity is one of the main drivers of social problem. Abortion related to sex determination and among third world countries like India female foeticide are burning problems across the world. In the era of upgraded ultrasound technology and capitalist novelty female foeticide has become a social jeopardy of international significance. In India, more than 10 million fetuses (female) have been terminated due to the reason of being girl. Report by Lancet Journal which is based in Canada and India, there were lost of 500000 girls annually. Since ancient days, killing of female foetus is an extraordinary feature under the rule of patriarchy in Indian society. Even now, it is reflected as when we notice the current scenario of child-sex ratio (between 0-6 age group); it is revealed that, it has been dropped dramatically since 2001 to 2011 in India (according to census) from 927 girls per 1000 boys in 2001 to 914 girls per 1000 boys in 2011. It is also noticed that in Indian society, the females are mostly dominated by the males and because of this number of females decline which is not a good indicator. That is why this paper tries to give emphasis on this burning issue which has a great significance to discuss in Indian male dominated society.

\section{OBJECTIVES}

1. To discuss the issue of female foeticide as an indicator of gender inequality in India.

2. To study about some causes of female foeticide in India.

3. To highlight some suggestive measures regarding this serious issue. 


\section{METHODOLOGY}

The present study illustrative in nature based on secondary sources of information. Secondary data have been collected from various sources like journals, research papers, books, government sources and reports of such other organizations like

a. Census of India 2011

b. Lok Sabha Unstarred Question No. 2753, dated on 11.03.2011

c. Lok Sabha Unstarred Question No. 3882, dated on 24.03.2017

d. Lok Sabha Unstarred Question No. 6967, dated on 08.05.2015

e. Lok Sabha Unstarred Question No. 2159, dated on 11.12.2015

f. Lok Sabha Unstarred Question No. 2559, dated on 17.03.2017

g. Lok Sabha Unstarred Question No. 4170, dated on 11.08.2017

h. Economic and Political Weekly, 2003

\section{EXPLORED LITERATURE REVIEW}

In all societies, violence against women is a very serious issue across the whole world. There is a very harmful effect of proceeding of gender determining violence. In developing countries like India, the burning issue of female foeticide is prevalent which is mostly considered as gender discriminating violence (Sarna, 2003). It is noticed that women have to go for sex determining abortion because they mostly believe in the cultural norms that if they do not give a baby boy then their entire lives are put at stake (Patel, $R$ 2007). The unwanted girl child may not get the proper treatment at their native home which may causing the sentimental and mental pain. So, due to this reason the supplier of service identified that the females may wanted to go for sex determining abortions because of their social desires (Economic and Political Weekly, 2003). I Ahmedabad, about 10000 cases were reported which is related to female foeticide (Gangrade, 1988:63-70). From some research, it is noticed that the modern medical opportunities are being go wrong or misused for determining the sex with the objective of aborting the foetus if it being a female foetus (Kulkarni, 1986; Diaz, 1988; Gangrade, 1988 and Bandewar, 2003). For past decades, female foeticide has been "spreading like a plague across Indian society" (Shiva, 2005, p. 137). Many studies have also emphasized the role of dowry or groom-price in instigating female-selective abortions (Das Gupta et al., 2003, pp. 15-16; Bhalla, 2004, p. 265).

\section{GENDER INEQUALITY}

In India, gender inequality or the gender gap considered to be an burning issue. The real picture of gender inequality in India is very intricate and various. Traditional patriarchal rituals and norms have entrusted females to a secondary position within the society mostly in household and workplace also. As per World Economic Forum's Gender Gap Index (GGI, 2014), gender disparity is known in India's low ranking position in achievement of education, involvement in economics and health status. Out of 146 countries, the country ranked $127^{\text {th }}$ position on the gender inequality index with a score of 0.563 and came $114^{\text {th }}$ in the world in terms of gender gap.
There is no any improvement in India in the overall gap of gender ranking (World Economic Forum) in 2018 compared to 2017. In 2018, it ranked at a low position 108 out of the 149 countries, the same as in 2017 . "India maintains a stable ranking this year, but its gap is directionally larger this year, with a 33 per cent gap yet to be bridged", says the report, titled Measuring the Global Gender Gap.

Table: 1 India's ranking in Gender-Gap Report

\begin{tabular}{|l|l|l|}
\hline & 2017 & 2018 \\
\hline Overall ranking & 108 & 108 \\
\hline $\begin{array}{l}\text { Economic participation \& opportunity } \\
\text { ranking }\end{array}$ & 139 & 142 \\
\hline Educational attainment ranking & 112 & 114 \\
\hline Health \& survival ranking & 141 & 147 \\
\hline Political empowerment ranking & 15 & 19 \\
\hline
\end{tabular}

Source: World Economic Forum

Types of gender inequality:

1. Inequality in Family

2. Natality inequality

3. Professional or employment inequality

4. Ownership inequality

5. Household inequality

6. Special opportunity inequality

Out of these types of gender inequality, this paper gives an emphasis on natality inequality, which ultimately leads to the direction of emerging and burning issue of female foeticide in India.

In natality inequality, parents wish the new born to be a boy not a girl so it indicates that natality inequality simply means gender inequality or disparity. In East Asia, China and South Korea this type of phenomenon can happen. Also in Singapore and Taiwan, this may happen. It is considered as a statistically significant phenomenon which can happen in India and South Asia as well.

\section{REASONS BEHIND FEMALE FOETICIDE}

According to the Indian Medical Association (IMA) around 5 million female foetuses are aborted each year. Excluding the mobile vans, there are around 20000 unregistered clinics, which are available for sex detection.

There are several factors which are responsible for the occurrence of the issue of female foeticide.

1. One of the notified cause of female foeticide is the dowry system in our society. In many poor class families due to fear of dowry system a couple of female foetuses are aborted.

2. Many parents has considered girl child as financial liability. Because after her marriage, the girl will go to her in-law's home so that it is considered that the money spend on her will be a total waste.

Published By:

Blue Eyes Intelligence Engineering \& Sciences Publication (C) Copyright: All rights reserved. 
3. Inflation is another burning issue of increasing the phenomenon of female foeticide in present day situation. So, due to this price rise, a couple think more times before giving birth to a girl child.

4. Another reason of female foeticide is the advancement of technology. Nowadays before birth of a child parent can determines the sex and kill the foetus if not according to their choice

5. Due to corruption the most dangerous phenomenon female foeticide may also happen because some physicians do this type of illegal works to attain their desire to money.

\section{THE SITUATION OF FEMALE FOETICIDE IN CURRENT SCENARIO:}

As India is basically a patriarchal society and it has a child sex ratio of 914, according to the census of 2011, which is even lower than all over female sex ratio. During last decade it decreased to $1.40 \%$. In 2001, child sex ratio was 927 . The females were treated as the divinity, who gives birth to the men, but in present day situation they are struggling for survival.

Table: 2. Sex Ratio of Child Population (0-6 Age Group), 1981-2011

\begin{tabular}{|l|l|l|l|l|}
\hline Year & India & Punjab & Haryana & Himachal \\
\hline 1981 & 962 & 908 & 902 & 971 \\
\hline 1991 & 945 & 875 & 879 & 951 \\
\hline 2001 & 927 & 798 & 819 & 896 \\
\hline 2011 & 914 & 846 & 830 & 906 \\
\hline
\end{tabular}

Source: Census of India

Table: 3. Sex Ratio of Total Population, 1981-2011

\begin{tabular}{|l|l|l|l|l|}
\hline Year & India & Punjab & Haryana & Himachal \\
\hline 1981 & 934 & 879 & 870 & 973 \\
\hline 1991 & 927 & 882 & 865 & 976 \\
\hline 2001 & 933 & 876 & 861 & 968 \\
\hline 2011 & 940 & 893 & 877 & 974 \\
\hline $\begin{array}{l}2011 \\
(7+ \\
\text { age })\end{array}$ & 944 & 899 & 855 & 983 \\
\hline
\end{tabular}

Source: Census of India

Female foeticide in India has now acquired country-wide dimension as sex ratio (females per 1000 males) of 0-6 years child population has suffered notable decline from 945 to 927 during 1991-2001 and then further from 927 to 914 during 2001-2011 (Table 2). On the other hand sex ratio of $7+$ year population has improved from 933 to 940 , and 940 to 944 respectively during the two decennial periods (Table 3 ). As per the 2001 census data, 0-6 year sex ratio (child sex ratio) had declined in 31 of the 35 states and union territories of the country during 1991-2001. Only Kerala, Pondicherry, and Lakshadweep had recorded rise in their child (0-6 year) sex ratios by 2, 4, and 18 units per thousand respectively. The corresponding figures for Jammu and Kashmir could not be worked out as no census was conducted in the state in 1991. However child sex ratio has improved a little in six states and two union territories during 2001-2011, as against one state and two union territories in the previous decade; but the overall national average for child sex ratio has declined further during this decade also (Table 2). Punjab and Haryana have the dubious distinction of being the leading states in female foeticide in the country. Sex determining abortion in the country manifests a social character which is the outcome of a distinct combination of social and cultural and also ritual values. It is estimated that 50 million girls and females are missing from the total number of population of India because of termination of the female foetus. The sex determining techniques are providing ample opportunity to the female foeticide \& socio-economic problems. Crime against girl child before their birth is a serious issue of above outcome. The following table defines the selected state-wise number of female foeticide cases registered in India (2010).

Table 4: Selected State-wise Number of Female Foeticide Cases Registered in India (2010)

\begin{tabular}{|l|l|}
\hline State/U Ts & $\mathbf{2 0 1 0}$ \\
\hline Andhra Pradesh & 1 \\
\hline Bihar & 0 \\
\hline Chhattisgarh & 4 \\
\hline Goa & 1 \\
\hline Gujarat & 9 \\
\hline Haryana & 3 \\
\hline Himachal Pradesh & 0 \\
\hline Karnataka & 2 \\
\hline Madhya Pradesh & 35 \\
\hline Maharashtra & 9 \\
\hline Orissa & 0 \\
\hline Punjab & 20 \\
\hline Rajasthan & 18 \\
\hline Uttar Pradesh & 0 \\
\hline West Bengal & 0 \\
\hline $\begin{array}{l}\text { Andaman and Nicobar } \\
\text { Island }\end{array}$ & 2 \\
\hline Delhi & 3 \\
\hline India & $\mathbf{1 0 7}$ \\
\hline & \\
\hline
\end{tabular}

Note: *: provisional

: Cases Foeticide Registered under Section 315 \& 316 Indian Penal Code (IPC)

Source: Lok Sabha Unstarred Question No. 2753, dated on 11.03.2011 From the above table it is clearly visible that Madhya Pradesh bears the highest number of registered cases regarding female foeticide in India in 2010, while Punjab reveals the second highest number and Rajasthan reveals the $3^{\text {rd }}$ highest number of registered female foeticide cases in India i.e. 20 and 18 respectively in the same year 2010. 
The following table tries to depict the current scenario regarding this issue as it defines state-wise number of cases registered and persons arrested under female foeticide in India during the time period of 2014-2016.

Table 5: Female Foeticide in India: Number of Caases Registered and Arrested Persons ( State-Wise; 20142016)

\begin{tabular}{|c|c|c|c|c|}
\hline \multirow[b]{2}{*}{ States/UTs } & \multicolumn{2}{|l|}{2014} & \multirow{2}{*}{$\begin{array}{l}2015 \\
\\
\text { Cases } \\
\text { registere } \\
\text { d }\end{array}$} & \multirow{2}{*}{$\begin{array}{l}2016^{*} \\
\\
\text { Cases } \\
\text { registere } \\
\text { d }\end{array}$} \\
\hline & $\begin{array}{l}\text { Cases } \\
\text { registe } \\
\text { red }\end{array}$ & $\begin{array}{l}\text { Persons } \\
\text { Arrested( } \\
\text { P) }\end{array}$ & & \\
\hline $\begin{array}{l}\text { Andaman and } \\
\text { Nicobar } \\
\text { Islands }\end{array}$ & 0 & 0 & 0 & 0 \\
\hline $\begin{array}{l}\text { Andhra } \\
\text { Pradesh }\end{array}$ & 2 & 0 & 3 & 5 \\
\hline $\begin{array}{l}\text { Arunachal } \\
\text { Pradesh }\end{array}$ & 0 & 0 & 0 & 0 \\
\hline Assam & 0 & 0 & 0 & 0 \\
\hline Bihar & 1 & 0 & 0 & 0 \\
\hline Chandigarh & 0 & 0 & 0 & 0 \\
\hline Chhattisgarh & 2 & NR & 2 & 0 \\
\hline $\begin{array}{l}\text { Dadra and } \\
\text { Nagar Haveli }\end{array}$ & 0 & 0 & 0 & 0 \\
\hline $\begin{array}{l}\text { Daman and } \\
\text { Diu }\end{array}$ & 0 & 0 & 0 & 0 \\
\hline Goa & 0 & 0 & 0 & 0 \\
\hline Delhi & 1 & 0 & 2 & 4 \\
\hline Gujarat & 0 & 0 & 0 & 1 \\
\hline Haryana & 2 & 0 & 4 & 1 \\
\hline $\begin{array}{l}\text { Himachal } \\
\text { Pradesh }\end{array}$ & 0 & 0 & 0 & 0 \\
\hline $\begin{array}{l}\text { Jammu and } \\
\text { Kashmir }\end{array}$ & 1 & 0 & 1 & 0 \\
\hline Jharkhand & 0 & 0 & 0 & 0 \\
\hline Karnataka & 9 & NR & 0 & 0 \\
\hline Kerala & 0 & 0 & 1 & 0 \\
\hline Lakshadweep & 0 & 0 & 0 & 0 \\
\hline $\begin{array}{l}\text { Madhya } \\
\text { Pradesh }\end{array}$ & 9 & 59 & 14 & 3 \\
\hline Maharashtra & 6 & 0 & 4 & 2 \\
\hline Manipur & 0 & 0 & 0 & 0 \\
\hline Meghalaya & 0 & 0 & 0 & 1 \\
\hline Mizoram & 0 & 0 & 0 & 0 \\
\hline Nagaland & 0 & 0 & 0 & 0 \\
\hline Odisha & 2 & 0 & 0 & 1 \\
\hline Puducherry & 0 & 0 & 0 & 0 \\
\hline Punjab & 4 & 0 & 3 & 6 \\
\hline Rajasthan & 10 & 2 & 5 & 7 \\
\hline Sikkim & 0 & 0 & 0 & 0 \\
\hline Tamil Nadu & 0 & 0 & 1 & 1 \\
\hline Telangana & 1 & 0 & 2 & 6 \\
\hline Tripura & 0 & 0 & 0 & 0 \\
\hline Uttar Pradesh & 0 & 0 & 3 & 2 \\
\hline Uttarakhand & 0 & 0 & 0 & 0 \\
\hline West Bengal & 0 & NR & 0 & 0 \\
\hline India & 50 & 61 & 45 & 40 \\
\hline
\end{tabular}

Abbr. : P : Provisional

Note : NR : Stands for Data not received.

*: Data is Provisional as Data is under Clarification.

Source : Lok Sabha Unstarred Question No. 6967, dated on 08.05.2015

Lok Sabha Unstarred Question No. 2159, dated on 11.12.2015

Lok Sabha Unstarred Question No. 2559, dated on 17.03.2017

Lok Sabha Unstarred Question No. 4170, dated on 11.08.2017

\section{FEMALE FOETICIDE: EFFECTS AND SOCIAL IMPACTS}

Due to the phenomenon of female foeticide the number of women is decreasing and because of this reason it is very much hard to find out girls to marry. And this type of phenomenon conducts the issue of girl's smuggling. According to a report, child sex ratio of Assam and West Bengle is very low in the country because the girls of these two states are kidnapped and sold them in the state of Haryana for marriage purpose. Men consider themselves more powerful and superior due to the dropping trend of women population and this gives the result of female's exploitation and abusement. Human trafficking may increase due to the expanded phenomenon of female foeticide. As per report, 15000 of women of India were bought and also sold in 2011.

\section{SOME SUGGESTIVE MEASURES TO CURB THE SERIOUS ISSUE FEMALE FOETICIDE}

When people realizing the importance of women in life, then only the social evil,i.e., female foeticide can be eradicated. Some suggestive measures for female foeticide are:

a) Registered all hospitals and Government should take some steps against the brutal action.

b) Government should take some initiatives to spread the issue regarding to sve the girl child through organizing some education oriented national level campaigning and also to talk about to the parents that they should not consider their girl child as liability.

c) In the area of education, reservation to the girl child should be provided and also support by providing minimum finance to the families that they may educate their girl child too. Anti dowry law may have taken by the Government and also provide financial support to the families regarding their girl's marriage.

d) Women empowerment should be emphasised. Women can take decision against the violation as they may become independent. 


\section{CONCLUSION}

Humorously, female foeticide takes place in a country where females are considered as Maa Laxmi's personification and where people worship various forms of Goddesses. I is also noticed that young girls are worshiped and touch their feet for blessings by the people. But in another way, the intentional killing of female foetus continues. So, this is a picture of our double standards of our society. In traditional type of families, the issue of female foeticide is more widespread. Therefore, to handling this type of problem, it is required to change the mind set. Mass appeal and social action must be required. Empowering the fundamental rights to Indian women. So, in conclusion, we can say that the awful illegal practice of female foeticide has to be interrupted by rigid laws and change the thinking pattern and decision of the people. So, it can say that For a better tomorrow save the girl child.

\section{REFERENCES}

1. Bandewar, S. (2003). "Abortion Services and Providers,Perceptions: Gender Dimensions", Economic and Political Weekly, Vol. 38, No. 21, pg. 2075-2081, May 24-30, 2003.

2. Chunkath, S.R. and V.B. Athreya (1997), "Female Infanticide in Tamil Nadu: Some Evidence”, Economic and Political Weekly, Vol. 17, ws pp. 22-29.

3. Dhar, Arati (2012), "42 per cent of Indian Children are Underweight”, The Hindu, October 10.

4. Kaur, R. (2008), "Dispensable Daughters and Bachelor Sons: Sex Discrimination In North India”, Economic and Political Weekly 43(30): 109-114.

5. Kulkarni, S. (1986). "Pre-Natal Sex Determination Tests and Female Foeticide in Bombay City". The Foundation for Research in Community Health, Bombay.

6. Kynch, Jocelyn \& Sen, Amartya (1983) "Indian Women: Wellbeing and Survival", Cambridge Journal of Economics, 7. 363-380.

7. Malhotra, Sarika. (2015), "India in the World Economic Forum Global Gender Gap Report 2015”, Business Today, November 23.

8. Nair, Shalini. (2015), "More Gender Inequality in India than Pakistan and Bangladesh: UN”, Indian Express, December 15.

9. Tandon, S. and Sharma, R. (2006). "Female Foeticide and Infanticide in India: An Analysis of Crimes Against Girl Children”, International Journal of Criminal Justice Science, Vol.1, No. 1, pp. 1-10, January, 2006.

\section{AUTHOR'S PROFILE}

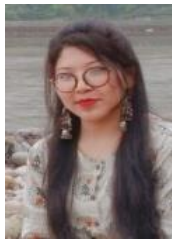

Pollypriya Buragohain. received Bachelor of Arts degree from Jagannath Baruah College, Jorhat in Economics under Dibrugarh University. She received Master of Arts in Economics from Dibrugarh University and presently she is pursuing M.Phil. Degree in Economics from Dibrugarh University, Dibrugarh, Assam , India. 